ECONOMIC THEMES (2018) 56(3): 413-438

sciendo

DOI 10.2478/ethemes-2018-0024

\title{
DETERMINANTS OF INNOVATION-BASED SUSTAINABILITY IN TRANSITION AND DEVELOPING ECONOMIES
}

\author{
Tanja Kuzman \\ Management School, University of Sheffield, Sheffield, United Kingdom \\ $\bowtie$ tkuzman1@sheffield.ac.uk \\ Sotirios K. Bellos \\ International Faculty-CITY College, University of Sheffield, Thessaloniki, Greece \\ $\bowtie$ sbellos@citycollege.sheffield.eu
}

Katarina Đulić

FEFA, Metropolitan University, Belgrade, Serbia

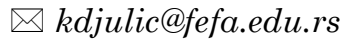

UDC

330.341.1:

502.131 .1

Original

scientific

paper

Received:

06.06.2018

Accepted:

22.08.2018

\begin{abstract}
Technological advancement enhanced by rising competition in a globalising world led to the acceleration of innovation activity. Literature implies that corruption, share of state ownership, and expertise of top management can have a strong influence on firms' performance and innovation-based sustainability. Using the BEEPS 2012-2014 database, this paper applies cross section analysis to examine this literature implication. Our results imply that larger manufacturing enterprises with experienced top management and international quality assurance certificates that operate in environments with increased corruption levels and competition have higher levels of innovation. In addition, the results show that state ownership is insignificant for innovation activity. In terms of regional analysis, we find that corruption, top management experience, and possession of international quality assurance certificates lead to an increase in product innovation in Balkan and former Soviet countries, while these factors do not create any significant impact on innovation activity within Central European countries. Enterprises faced with fierce competition levels are more innovative in former Soviet and Central European countries than in the Balkans.
\end{abstract}

Keywords: innovation, competition, corruption, state-owned enterprises

JEL classification: O31, G34, D21, M21 


\section{Introduction}

Accelerating technology and fierce competition have led to innovation becoming a critical enterprise performance and competitiveness indicator. Kueng (2000) emphasises that enterprises need to constantly upgrade their products and services in order to keep up with their competitors. Cox, Issa, and Ahrens (2003) confirm this standing, explaining that nowadays innovation is critical for enterprises' longterm success as well as for their survival in globalised markets where competition pressures are ever more salient. Sawang (2011) adds that enterprises assume that investments in innovation result in productivity improvements and provide enterprises with competitive advantage.

European innovation records were always considered high. During the last two decades, a series of critical changes took place that had a direct impact on European enterprises. The collapse of the centrally planned economic system and the re-orientation of several economies towards open economy principles, as well as the global financial crisis in 2008 , had severe effects on the operation of firms, their potential to face international competition successfully, and their motives to provide innovative products and services. Innovation embodies all elements of the ability to cope effectively with fierce globalised market powers (Kueng, 2000; Hana, 2013). Therefore, the study of an economy's ability to innovate is in several terms synonymous to studying the rate of its embodiment and its ability to survive in the contemporary open market structures (Aubert, 2005).

This paper investigates the relationship between corruption, share of state ownership, expertise of top management, and innovation-based sustainability in transition and developing economies through the application of a cross sectional analysis using the Business Environment and Enterprise Performance Survey (BEEPS) 2012-2014 database. We find that big manufacturing enterprises, which faced fierce competition, employed experienced top management, and paid bribes, have higher levels of product innovation. As a regional specificity, we find that corruption, top management expertise, and possession of international quality assurance certificates increase innovation levels in Balkan and former Soviet countries, while these factors are insignificant for innovation levels in Central European countries.

Our paper contributes to the existing literature in several important aspects. First, we contribute to the theory on determinants of enterprise performance by looking at determinants of innovation-based sustainability. Second, the period examined (2012-2014) represents the peak of the crisis waves in Europe, thus showing the aspects of the innovation nexus within the global financial crisis. Therefore, the current study offers a wide view of one of the critical factors of economic excellence in relation to the prevailing institutional and business characteristics in some of the most sensitive and strategic areas and during a period of intensive economic and financial turmoil. Third, our study categorises transition 
economies into three different geographic groups in order to demonstrate different innovation patterns related to certain structural and institutional features. As a result, our research identifies policy, cultural, and political/geopolitical causes behind the regional differences.

The paper is structured/organised as follows. The second section reviews the literature in order to define innovation and explain how different external and internal governance factors influence innovation-based sustainability of State Owned Enterprises (SOEs). The third section describes data and methodology, while the fourth section presents and discusses empirical results. Section five offers a conclusion.

\section{Which factors affect innovation-based sustainability of enterprises?}

Schumpeter was one of the first researchers to define innovation and innovative action back in 1911. His view was that innovation is the transformation of new ideas into reality. In this way, he claimed that innovative actions encompass the introduction of new products, new ways of production, entering new markets, new supply sources, and new market structures in an industry (Schumpeter, 1911). Gradually, innovation theories were built on Schumpeter's standing. In the 1950s and 1960s, technological development was recognised as the main driver of innovation, while in the 1980s and 1990s, it was recognised that innovation has to encompass a systemic approach with integrated institutions (OECD, 1999; Rothwell, 1994). In this paper, innovation is defined as the introduction of a new good or service with significantly improved characteristics and/or usage features, since this is the most common definition of innovation in studies employing enterprise-level data (e.g. Krammer, 2013; Molero \& Garcia, 2008; OECD, 2005; Aghion, Carlin, \& Schaffer, 2002; Hellman, Jones, \& Kaufmann, 2000).

Even though the definition of innovation has evolved through time, for researchers it was always clear that innovation contributes and enhances economic development and competitiveness (Rosenberg, 2004; Cameron, 1996; Romer, 1990). Aghion and Howitt (1992), Grossman and Helpman (1991), and Romer (1990) emphasise that economic growth in the long run is not merely the result of investment levels, but rather innovation levels. Therefore, if we want to trace indirect channels through which corruption influences economic growth, it is crucial to understand whether and how corruption influences innovation, apart from other ways in which it influences growth (Habiyaremye \& Raymond, 2013). If we draw the same parallel for enterprises, it becomes quite obvious why corruption needs to be taken into account when evaluating enterprise performance. Yet, despite the fact that the impact of corruption on economic growth has been vastly debated, its impact on enterprise innovation levels has received limited attention. Most scholars (e.g. Campos, Dimova, \& Saleh, 2010) believe that 
corruption harms economic development and innovative performance. Researchers who engaged with this topic find that corruption is harmful for enterprise innovation activities (Waldemar, 2012; Anokhin \& Schulze, 2009; Murphy, Shleifer, \& Vishny, 1993). Luo (2005) identifies a firm's dynamic capabilities as crucial growth enhancing factors. These capabilities include continuous innovation and innovative corporate culture as well as knowledge upgrading. However, Luo points out that these capabilities can bear fruit only in a competitive environment. In an environment poisoned by bribery and corruption, an enterprise is more likely to focus its resources on the development of corruptive strategies since it believes that these are more likely to help it realise organisational objectives relative to the firm's dynamic capabilities. Apart from this diversion of resources, an innovative enterprise in a bribery culture and corruptive environment might even be penalised. Ayyagari, Demirgtic-Kunt, \& Maksimovic (2010) find that enterprises with higher levels of innovative activities are those that have to pay higher levels of bribes. In a different approach, Bellos and Subasat (2012), focussing also on transition economies, find that foreign direct investment (FDI) is not deterred by high corruption levels prevailing in these countries. Furthermore, Asiedu and Freeman (2009) find that corruption, in a "grease the wheel" approach, may lead to an increase in investments in developing countries since enterprises may benefit from corruption activities (e.g. access to raw materials at subsidised prices, reduction of tax payments, etc.). This argument states that inefficient institutions hamper the growth of enterprises in less developed economies (Huntington, 1968; Leys, 1965; Leff, 1964). Lui (1985) shows that, in a formal economic model, corruption will free resources that would otherwise be wasted in queuing caused by an illfunctioning bureaucracy. Similarly, Vial and Hanoteau (2010) claim that many emerging markets with low quality institutional environments tend to perform better in terms of innovation and economic growth despite rampart corruption. On the other hand, Shleifer and Vishny (1993) warn that this impression might be poorly rooted in reality. They specifically highlight that it is common that corrupt enterprises tend to report having advanced technologies, even though they are not needed and/or existent, just to obtain some benefits. These results leave an impression that the amount of innovative activity is larger in these countries than it is in reality. Along the same lines, Mahagaonkar (2008) shows, on a newly available dataset of African enterprises, that corruption has a negative effect on product and organisational innovation and that it does not affect process innovation, while it facilitates marketing innovation. Based on stated arguments, it seems that corruption is one of the significant factors affecting innovation levels and, as such, it has to be included in our model. Aside from corruption, which other factors are important for the level of innovation?

Several researchers find that human capital, level of competition, and research and development (R\&D) investments affect the level of innovation in an enterprise (McCann \& Oxley, 2012; Lederman, 2010; Furman, Porter, \& Stern, 2002). Nickell (1996) and Blundell, Griffith, \& Van Reenen (1999) show that competition 
positively impacts the number of innovations in an observed sample of UK enterprises. Carlin, Fries, Schaffer, \& Seabright (2001) confirm these results, concluding that enterprises experiencing fierce competition are more likely to be the ones to introduce new products. Furthermore, Aghion et al. (2002) find evidence that the competition-innovation relationship for UK enterprises takes the form of an inverted-U shape. Trying to explain the shape of the curve, the authors develop a model in which competition may increase the incremental profit from innovation, the so-called "escape-competition effect", but it may also reduce innovation incentives for laggards, an effect that the authors label the "Schumpeterian effect". In the so-called "levelled sectors" where observed enterprises are at technological par with one another, competition induces these enterprises to innovate in order to escape competition. However, in "unlevelled sectors", where one enterprise is the leader and is always one step ahead of its competitors (laggards or followers), we witness a reduction of rents that can be captured by followers who succeed in catching up with the leader by innovating. This Schumpeterian argument states that large enterprises in concentrated markets have an advantage in innovation. Nevertheless, Ahn (2002) claims that there is little empirical evidence to support the argument that market concentration is conducive to innovation.

As the vast majority of the sample economies are transition ones, which applied principles of a centrally planned economy for several decades, it is important to examine the association of the state character of several business firms (SOEs) with the attained innovation levels, reflecting in this way their efficiency and competitiveness potential. The 2008 crisis and its fiscal consequences seem to have reframed this debate. Even before the crisis, when the privatisation efforts worldwide were in full swing, corporatisation of SOEs in many countries made profitability measures more prominent (Brown, 1995; Bozec, Breton, \& Cote, 2002). The expectation that the cost of pursuing non-commercial goals should be clearly and transparently borne by the government started to be openly promulgated (OECD, 2015; Laux \& Molot, 1988). In the last decade, Musacchio (2013) observes further separation of ownership and control in SOEs. Subsidising social and political objectives in times of greater fiscal constraints imposed by the crisis forced many governments to insist more aggressively on greater profitability and better governance in SOEs. Aware of these trends, the OECD (2015) suggests that SOEs should be required to generate rates of return that are, in the long run, comparable to those of their private competitors. Inefficiencies in the governance of SOEs derive from a number of specificities related to the characteristics of SOEs, but they mainly arise from weaknesses in external and internal governance systems (e.g. World Bank, 2014; Christiansen, 2013; Capobianco \& Christiansen, 2011; OECD, 2011; Wang \& Yung, 2011; Chang, 2007; World Bank, 2006; Wong, 2004; World Bank, 1995). The existence of the third agency problem (behaviour of the state/government as owner) is recognised as the main factor from which major problems in external governance of SOEs emerge (Christiansen, 2013; Capobianco 
\& Christiansen, 2011; Wang \& Yung, 2011). The agency problem exists in each enterprise in which the owners of the enterprise do not manage it. Whether the owner is a physical person, a legal person, or a state is irrelevant. In each case, the owners (principals) incur substantial agency costs trying to monitor their agents in order to ensure that the agents act in the principals', and not their own, interests (Jensen \& Meckling, 1976). However, in SOEs, the agency problem has a specificity that is not present in private enterprises. This specificity is known in the literature as "the third agency problem", and it demonstrates that in this type of enterprises there are three, instead of two, layers of governance. Within SOEs, citizens are the ultimate owners representing distinctive stakeholders, the government is a "fiduciary agent" with an obligation vis-à-vis its citizens to select the optimal board to govern the enterprise, and the board of directors is a "direct agent" that governs the enterprise (Musacchio, Pineda Ayerbe, \& García, 2015; Capobianco \& Christiansen, 2011). The citizens cannot competently supervise their direct agents due to their limited knowledge and resources, thus, entrusting supervision to the government. This chain of agents is a generator of inefficiencies that are specific to SOEs and additional to standard agency challenges that also exist in private enterprises. For that reason, it is argued that the level of state ownership can have a strong influence on SOE performance and sustainability. The World Bank (2014), Shleifer (1998), Megginson, Nash, \& Van Randenborgh (1994), and Boardman and Vining (1989) find that one of the external governance factors mentioned frequently in the literature that contributes significantly to SOE inefficiencies is the presence of corruption. On the other hand, the performance level of top management expertise is depicted as one of the most important internal governance factors that affect SOEs (World Bank, 2014; Chang, 2007; World Bank, 1995; Baumol, 1980). Due to the fact that not many researchers have used innovation as an SOE performance measure, our research focusses on the effects of corruption, share of state ownership, and other external and internal governance factors on SOE innovation.

When it comes to other factors that might affect innovation, Ayyagari, Demirgtic-Kunt, \& Maksimovic (2011) and Aghion et al. (2002) show that the existence of soft budget constraints and state ownership have a negative impact on enterprise-level innovation. La Porta, Lopez-de-Silanes, Shleifer, \& Vishny (2002) analyse differences between private and state-owned enterprises and conclude that SOEs have relatively higher inefficiency levels that ultimately lead to a lower rate of innovation. Furthermore, the literature suggests that bigger enterprises can allocate more resources for R\&D activities, which translate into more innovation (Cohen \& Klepper, 1996). Freeman and Soete (1997) also find that the size of the enterprise influences innovation. They explain that size "certainly influences what kind of projects can be attempted in terms of technology, complexity and costs but does not in itself determine the outcome" (Freeman \& Soete, 1997, p. 193). Lederman (2010), Raffo, Ghuillery, \& Miotti (2008), Molero and Garcia (2008), and Aghion et al. (2002) later confirm this finding. Hansen (1992) claims that apart 
from size, management experience is also crucial for innovative activities. The most recent empirical studies show that managerial practices differ among countries and that they highly influence the sustainability of enterprises in the long run (Bloom \& Van Reenen, 2010; Holcomb, Holmes, \& Connely, 2009). In addition, De Rosa, Gooroochurn, \& Gorg (2010), Molero and Garcia (2008), and Aghion et al. (2002) find that innovation activity is dependent and highly influenced by the sector in which an enterprise operates. Furthermore, innovation levels are affected by the presence/absence of international standards in the form of certificates/licenses (Lederman, 2010). Finally, age cannot be left outside of the context. Within models that look at how corruption impacts different performance measures, researchers usually control for enterprise age and find no significant relationship between these two variables (De Rosa et al., 2010; Gaviria, 2002).

\section{Data and methodology}

In order to determine the relationship between different factors and innovationbased sustainability, we have derived data from the latest BEEPS, a joint initiative of the European Bank for Reconstruction and Development and the World Bank Group. The latest and fifth round of BEEPS 2012-2014 covered 15,883 entities from 30 Eastern European and Central Asian countries. ${ }^{1,2}$ The BEEPS data exhibit a stratified random sample and represent enterprise-level data derived from face-toface interviews with enterprise managers. The survey is composed of 17 sections that look at general information about the enterprise and the extent to which government policies and practices impede or boost business activity. A standardised survey instrument is used in the creation of the BEEPS databases, while a uniform sampling methodology is employed in order "to minimise measurement error and to yield data that are comparable across the world's economies" (p. 2). ${ }^{3}$ BEEPS has been utilised by many researchers. ${ }^{4}$ Using BEEPS, Mitra, Muravyev, \& Schaffer (2009) look at the convergence of countries with a focus on competition, market structure, finance, etc. Hellman, Jones, \& Kaufmann (2003) investigate the economic dynamics of state capture.

Nevertheless, research based on BEEPS is not deprived of the general concern that results might not be reliable due to individual perception bias - the tendency of individuals to overestimate or underestimate the real economic situation within a country (Hellman et al., 2000; Kaufman \& Wei, 2000). However, Fries, Lysenko,

${ }^{1}$ http://ebrd-beeps.com/data/2012-2013/

2 Albania, Armenia, Azerbaijan, Belarus, Bosnia and Herzegovina, Bulgaria, Croatia, Czech Republic, Estonia, Former Yugoslav Republic of Macedonia, Georgia, Hungary, Kazakhstan, Kosovo (under UNSCR 1244), Kyrgyzstan, Latvia, Lithuania, Moldova, Mongolia, Montenegro, Poland, Romania, Russia, Serbia, Slovakia, Slovenia, Tajikistan, Turkey, Ukraine and Uzbekistan.

${ }^{3} \mathrm{http} / / /$ ebrd-beeps.com/wp-content/uploads/2013/09/beeps_v_qm_nonrus.pdf

${ }^{7}$ Habiyaremye and Raymond (2013), Krammer (2013), De Rosa et al. (2010), Mitra et al. (2009), Hellman et al. (2003), Aghion et al. (2002), Hellman et al. (2002), Hellman et al. (2000), etc. 
\& Polenac (2003) and Hellman et al. (2000) check for this perception bias in BEEPS data and find no supporting evidence for the existence of such bias. Since all other BEEPS data follow almost the same methodology, De Rosa et al. (2010) explain that "we may be reasonably confident that perception bias will not affect the results of our analysis" (p.11).

Within the scope of this paper, we define innovation as the process of development and the introduction of new goods or services. Values for this variable are derived from the answers to the following question: "During the last three years has this establishment introduced new or significantly improved products or services? Please exclude the simple resale of new goods purchased from others and changes of a solely aesthetic nature." The innovation variable employed within our model is therefore a binary/dichotomous variable with values 1 -yes and 0 -no.

When it comes to quantifying corruption, it is quite important to mention that all corruption-related measures are based exclusively on individuals' perceptions. Even though BEEPS provides several corruption measures, we have decided to employ the measure for which the highest level of honesty and objectiveness is expected. As corruption is a quite sensitive topic, most enterprises are reluctant to reveal information on how much they spent on bribes the year before or what percentage of sales is used for increasing probability that something is done by public administration. Therefore, it was decided to measure corruption based on agreement/disagreement with the following statement: "It is common for firms in my line of business to have to pay some irregular 'additional payments or gifts' to get things done with regard to customs, taxes, licenses, regulations, services, etc." Respondents could answer using a scale where 1 was equal to "never" and 6 was equal to "always".

Since we wanted to see whether state ownership influences innovation, we used a variable that shows the percentage of state ownership. Based on the literature review, it was also decided to employ the age variable, which is calculated by subtracting the year that the enterprise was established from the year in which the survey was conducted. In addition, the size variable (the total number of full-time employees) and the sector variable (enterprises are divided into two groups manufacturing and services) were also employed. Since Aghion, Blundell, Griffith, Howitt, \& Prantl (2009) find that competition and innovation are interconnected, a variable that represents a proxy of competition levels was also selected. The level of competition is measured by the number of competitors that individual enterprises have in their line of business. In order to determine whether management experience creates an impact on innovation, as has been implied in the literature, the model also uses the variable that represents the years that the top manager spent in that specific industry. The last two variables employed within the model are soft budget constraint and the presence/absence of certificates. The first variable is derived from the data on whether the most recent line of credit or loan 
was granted by a state-owned bank or government agency (1-yes; 0 -no), while the second variable is based on the possession of an internationally-recognised quality certification (1-yes; 0-no). Appendix A, Table 1 contains the definitions for all variables used within this paper as well as a reference to the BEEPS questionnaire.

Our sample comprises 15,883 enterprises (small deviations from this number are present for certain variables due to missing observations). Table 1 provides descriptive statistics for all variables used within our research. Enterprises included in our sample employ on average 65 employees, which implies that a large number of small and medium sized enterprises is included in our sample. These enterprises exist on average 14 years and they are led by top managers with on average 16 years of experience on average in the same sector in which the enterprise operates. Furthermore, within our sample, the enterprises' main product faces on average five competitors on the main market where it is sold.

Table 1. Descriptive statistics 5

\begin{tabular}{lccc}
\hline Variable & Mean & Std & Obs \\
\hline Product innovation & 0.24 & 0.43 & 15,797 \\
Share of state ownership & 0.01 & 0.08 & 15,720 \\
Enterprise size & 64.93 & 1.25 & 15,778 \\
Enterprise existence & 14.39 & 0.73 & 15,715 \\
Top management experience & 16.62 & 0.73 & 15,396 \\
Certificate & 0.23 & 0.42 & 15,502 \\
Competition & 5.01 & 0.78 & 12,929 \\
Soft budget constraint & 0.06 & 0.23 & 15,883 \\
Corruption & 0.50 & 0.56 & 14,572 \\
Sector & 0.40 & 0.49 & 15,883 \\
\hline
\end{tabular}

Source: Authors' calculations

In our research we use OLS, LOGIT, and PROBIT methodology to demonstrate the robustness of our results. Since our dependent variable is dichotomous, the usage of only OLS methodology, which creates a linear fit of the data, may in some cases provide misleading results. Therefore, we also employ LOGIT and PROBIT methodologies, which are used whenever the dependent variable is dichotomous, as they provide a better fit of the data. After running these three models, we add a country dummy variable in each of them and rerun them. By doing so, we control for any differences that may exist between the countries within our sample and further show the robustness of our results. Additionally, we divide our sample into three different geographical regions (Balkan countries, Central European countries, and former Soviet countries) in order to control for regional differences.

${ }^{5}$ For Enterprise size, Enterprise existence, Top management experience, and Competition, we report descriptive statistics of level values, while we use log values of these variables in our estimations. 


\section{Empirical results}

\subsection{Empirical results for the whole sample}

Table 2 shows the results of our OLS, LOGIT, and PROBIT estimates. The results demonstrate no deviation between the different methods/models employed, suggesting that our results are robust. Only two variables seem to be insignificant for product innovation, while all other independent variables are significant at $1 \%$ significance level (the only exception is soft budget constraint, which is significant at a $5 \%$ significance level).

Table 2. Factors influencing innovation-based sustainability of SOEs

\begin{tabular}{|c|c|c|c|c|c|c|}
\hline & OLS & $\begin{array}{c}\text { OLS } \\
\text { (country } \\
\text { dummy) }\end{array}$ & LOGIT & $\begin{array}{l}\text { LOGIT } \\
\text { (country } \\
\text { dummy) }\end{array}$ & PROBIT & $\begin{array}{l}\text { PROBIT } \\
\text { (country } \\
\text { dummy) }\end{array}$ \\
\hline \multirow{2}{*}{$\begin{array}{l}\text { Share of state } \\
\text { ownership }\end{array}$} & -0.068 & -0.063 & -0.374 & -0.331 & -0.229 & -0.202 \\
\hline & $(0.056)$ & $(0.056)$ & $(0.327)$ & $(0.337)$ & $(0.192)$ & $(0.199)$ \\
\hline Enterprise size & $\begin{array}{c}0.028 * * * \\
(0.004)\end{array}$ & $\begin{array}{c}0.031 * * * \\
(0.004)\end{array}$ & $\begin{array}{c}0.148 * * * \\
(0.020)\end{array}$ & $\begin{array}{c}0.180 * * * \\
(0.021)\end{array}$ & $\begin{array}{c}0.088 * * * \\
(0.012)\end{array}$ & $\begin{array}{c}0.106 * * * \\
(0.012)\end{array}$ \\
\hline \multirow[t]{2}{*}{$\begin{array}{l}\text { Enterprise } \\
\text { existence }\end{array}$} & 0.005 & -0.000 & 0.025 & 0.000 & 0.017 & -0.000 \\
\hline & $(0.006)$ & $(0.006)$ & $(0.036)$ & $(0.039)$ & $(0.021)$ & $(0.023)$ \\
\hline \multirow[t]{2}{*}{$\begin{array}{l}\text { Top management } \\
\text { experience }\end{array}$} & $0.022 * * *$ & $0.018 * * *$ & $0.125 * * *$ & $0.114 * * *$ & $0.074 * * *$ & $0.064 * * *$ \\
\hline & $(0.006)$ & $(0.006)$ & $(0.035)$ & $(0.038)$ & $(0.020)$ & $(0.022)$ \\
\hline Certificate & $\begin{array}{c}0.080 * * * \\
(0.011)\end{array}$ & $\begin{array}{c}0.077 * * * \\
(0.011)\end{array}$ & $\begin{array}{c}0.398 * * * \\
(0.055)\end{array}$ & $\begin{array}{c}0.414 * * * \\
(0.060)\end{array}$ & $\begin{array}{c}0.241^{* * *} * \\
(0.033)\end{array}$ & $\begin{array}{c}0.245^{*} * * \\
(0.035)\end{array}$ \\
\hline Competition & $\begin{array}{c}0.030 * * * \\
(0.005)\end{array}$ & $\begin{array}{c}0.016^{* * * *} \\
(0.005)\end{array}$ & $\begin{array}{c}0.162 * * * \\
(0.028)\end{array}$ & $\begin{array}{c}0.088 * * * \\
(0.029)\end{array}$ & $\begin{array}{c}0.096^{* * *} * \\
(0.016)\end{array}$ & $\begin{array}{c}0.055^{*} * * \\
(0.017)\end{array}$ \\
\hline \multirow[t]{2}{*}{$\begin{array}{l}\text { Soft budget } \\
\text { constraint }\end{array}$} & $0.036^{* *}$ & 0.030 & $0.184 * *$ & 0.158 & $0.109^{* *}$ & 0.094 \\
\hline & $(0.018)$ & $(0.018)$ & $(0.091)$ & $(0.098)$ & $(0.055)$ & $(0.058)$ \\
\hline Corruption & $\begin{array}{c}0.042 * * * \\
(0.007)\end{array}$ & $\begin{array}{c}0.034 * * * \\
(0.007)\end{array}$ & $\begin{array}{c}0.233 * * * \\
(0.040)\end{array}$ & $\begin{array}{c}0.196^{* * *} \\
(0.043)\end{array}$ & $\begin{array}{c}0.135^{* * *} * \\
(0.023)\end{array}$ & $\begin{array}{c}0.112 * * * \\
(0.025)\end{array}$ \\
\hline Sector & $\begin{array}{c}0.083 * * * \\
(0.009)\end{array}$ & $\begin{array}{c}0.127 * * * \\
(0.009)\end{array}$ & $\begin{array}{c}0.444 * * * \\
(0.046)\end{array}$ & $\begin{array}{c}0.720 * * * \\
(0.050)\end{array}$ & $\begin{array}{c}0.261 * * * \\
(0.027)\end{array}$ & $\begin{array}{c}0.424 * * * \\
(0.030)\end{array}$ \\
\hline $\mathrm{N}$ & 11,169 & 11,169 & 11,169 & 11,169 & 11,169 & 11,169 \\
\hline $\mathrm{R} 2^{6}$ & 0.039 & 0.104 & & & & \\
\hline Pseudo_R2 & & & 0.035 & 0.099 & 0.035 & 0.099 \\
\hline
\end{tabular}

***Significance at $1 \%$ level; **Significance at $5 \%$ level; *Significance at $10 \%$ level. Robust standard errors in parentheses.

Source: Author calculations

${ }^{6}$ It can be noticed that R2 and Pseudo_R2 have low values, but in qualitative models these have limited importance. 
The results clearly imply that the percentage of state ownership is insignificant for innovation levels. This means that the presence of the state/government as owner does not influence innovation activities within enterprises. Therefore, our results fail to confirm the findings of Shleifer (1998) and La Porta et al. (2002) who show that higher levels of innovation are present within privately owned enterprises. Furthermore, our findings are not in line with the results of Ayyagari et al. (2011) and Aghion et al. (2002) who imply that enterprises with state ownership will innovate to a lesser extent.

Table 2 also provides evidence of a significant positive impact of corruption on product innovation, implying the existence of a pass-through effect of corruption on innovation. In economic terms, this means that enterprises that are involved in corruptive activities create a higher number of innovative products when compared to enterprises not involved in such activities. The reasoning behind this trend is provided by Murphy et al. (1993) who explained that innovative enterprises are more dependent on government-supplied services/goods (e.g. permits, licenses, certificates) due to which they are more exposed to involvement in corruptive activities. Moreover, they explain that the need for obtaining registration for a new product/trademark or similar increases the interaction of these enterprises with government representatives thus leading to higher bribe payments before the innovative product is created (Murphy et al., 1993). This is confirmed by Ayyagari et al. (2010) who find that enterprises that spend on average $0.37 \%$ more of their sales on corruptive activities are enterprises with higher levels of innovation.

If we look further at the results provided in Table 2, a significant positive effect of competition on product innovation is noticeable. This is in line with the conclusion of McCann and Oxley (2012), Lederman (2010), and Furman et al. (2002) who also find that an increase in the level of competition positively influences innovation levels. Allen and Gale (2000) explain that in developing countries, with an increase in the intensity of competition, enterprises are faced with rather limited space for departing from innovation activities and efficient investments. The results also demonstrate a significant positive impact of soft budget constraints on innovation levels, which confronts the findings of Ayyagari et al. (2011) and Aghion et al. (2002). These results seem to imply that in developing and transition countries, soft budget constraints provide enterprises with additional funding and/or cheaper sources of funds, hence enabling them to invest higher amounts of money in R\&D. The findings also reveal that the possession of international quality assurance certificates boosts innovation since this creates additional incentives for enterprises and enables them to place their products to customers who are sensitive to the presence/absence of international quality assurance.

Despite the usual belief that innovation is a creative activity for which experience is not so important, our results show that the experience of top management contributes positively to innovation levels. This finding conforms with the conclusion of Ayyagari, Demirgtic-Kunt, \& Maksimovic (2007) that enterprises led 
by managers with three to ten years of experience are more likely to innovate and introduce new products. This trend can be due to the ability of experienced top managers to streamline $R \& D$ funds towards projects that generate higher levels of innovation and/or their ability to efficiently and effectively use $R \& D$ funds. Moreover, experienced top managers are able to put innovation high on the priority agenda as well as create an innovative atmosphere within an enterprise.

When it comes to enterprise characteristics, the results show that the age of an enterprise is insignificant, which confirms a similar finding of Gaviria (2002). In terms of enterprise size, our results support the findings of Lederman (2010), Raffo et al. (2008), Molero and Garcia (2008), Ayyagari et al. (2007), and Aghion et al. (2002). This positive significant impact of enterprise size on innovation is expected since larger enterprises usually have bigger R\&D budgets, which allow for greater innovation levels (Cohen \& Klepper, 1996). Furthermore, a high positive significance of the industry with regard to the level of innovation confirms the standing that greater levels of product innovation are observed in manufacturing sectors that are highly dependent on technology (De Rosa et al., 2010; Molero \& Garcia, 2008; Aghion et al., 2002).

\subsection{Empirical results for groups of countries}

As mentioned previously, the BEEPS 2012-2014 database covers 15,883 enterprises from 30 Eastern European and Central Asian countries. Some of the countries within the sample are members of the European Union, some of them have gone through huge transformations from centrally planned economic regimes to that of open markets, some of them are far more developed than others, etc. This variety means that the countries included in the sample have differences and similarities based on which groups of countries can be differentiated. Within our research, we have decided to classify countries into three geographical groups/subsamples - Balkan countries, ${ }^{7}$ Central European countries, ${ }^{8}$ and former Soviet countries. ${ }^{9}$ Our aim is to see whether there are any differences/similarities in the factors that influence product innovation levels in these groups of countries. In Table 3, we show the results of LOGIT and PROBIT estimations (without country dummy) for each group of countries in order to be able to see which factors influence product innovation in each of them. Further results, which demonstrate the robustness of data in Table 3, can be found in Appendix B within Table 1, Table 2, and Table 3 .

\footnotetext{
${ }^{7}$ Albania, Bosnia and Herzegovina, Bulgaria, Croatia, Former Yugoslav Republic of Macedonia, Kosovo (under UNSCR 1244), Montenegro, Romania, Serbia, Slovenia.

${ }^{8}$ Czech Republic, Estonia, Hungary, Latvia, Lithuania, Poland, Slovakia (even though it can be argued that Estonia, Latvia, and Lithuania were part of the former Soviet Union, we consider them to be Central European countries due to their geographical position).

9 Armenia, Azerbaijan, Belarus, Georgia, Kazakhstan, Kyrgyzstan, Moldova, Russia, Tajikistan, Ukraine, Uzbekistan.
} 
Kuzman et al. / Economic Themes, 56(3): 413-438

Table 3. Factors influencing innovation-based sustainability of SOEs in Balkan, former Soviet, and Central European countries

\begin{tabular}{|c|c|c|c|c|c|c|}
\hline & \multicolumn{2}{|c|}{ Balkan countries } & \multicolumn{2}{|c|}{$\begin{array}{c}\text { Former Soviet } \\
\text { countries }\end{array}$} & \multicolumn{2}{|c|}{$\begin{array}{c}\text { Central European } \\
\text { countries }\end{array}$} \\
\hline & LOGIT & PROBIT & LOGIT & PROBIT & LOGIT $^{10}$ & PROBIT \\
\hline \multirow{2}{*}{$\begin{array}{l}\text { Share of state } \\
\text { ownership }\end{array}$} & -1.578 & -0.902 & -0.218 & -0.134 & 0.000 & 0.000 \\
\hline & (1.379) & $(0.807)$ & $(0.364)$ & $(0.212)$ & (.) & (.) \\
\hline \multirow{2}{*}{$\begin{array}{l}\text { Enterprise } \\
\text { size }\end{array}$} & $0.081 * *$ & $0.050 * *$ & $0.250 * * *$ & $0.146 * * *$ & $0.198 * * *$ & $0.121 * * *$ \\
\hline & $(0.041)$ & $(0.025)$ & $(0.027)$ & $(0.016)$ & $(0.054)$ & $(0.033)$ \\
\hline \multirow{2}{*}{$\begin{array}{l}\text { Enterprise } \\
\text { existence }\end{array}$} & 0.059 & 0.035 & $-0.093^{*}$ & $-0.052 *$ & 0.106 & 0.061 \\
\hline & $(0.079)$ & $(0.047)$ & $(0.048)$ & $(0.028)$ & (0.119) & $(0.071)$ \\
\hline \multirow{2}{*}{$\begin{array}{l}\text { Top } \\
\text { management } \\
\text { experience }\end{array}$} & $0.142^{*}$ & $0.086^{*}$ & $0.196 * * *$ & $0.110 * * *$ & -0.038 & -0.021 \\
\hline & $(0.076)$ & $(0.046)$ & $(0.048)$ & $(0.027)$ & $(0.100)$ & $(0.060)$ \\
\hline Certificate & $\begin{array}{c}0.562 * * * \\
(0.103)\end{array}$ & $\begin{array}{c}0.345 * * * \\
(0.063)\end{array}$ & $\begin{array}{c}0.384 * * * \\
(0.087)\end{array}$ & $\begin{array}{c}0.232 * * * \\
(0.052)\end{array}$ & $\begin{array}{c}0.074 \\
(0.141)\end{array}$ & $\begin{array}{c}0.042 \\
(0.084)\end{array}$ \\
\hline Competition & $\begin{array}{l}-0.036 \\
(0.051)\end{array}$ & $\begin{array}{c}-0.022 \\
(0.031)\end{array}$ & $\begin{array}{c}0.191 * * * \\
(0.041)\end{array}$ & $\begin{array}{c}0.109 * * * \\
(0.024)\end{array}$ & $\begin{array}{c}0.188 * * \\
(0.074)\end{array}$ & $\begin{array}{c}0.116^{* * *} \\
(0.045)\end{array}$ \\
\hline \multirow{2}{*}{$\begin{array}{l}\text { Soft budget } \\
\text { constraint }\end{array}$} & -0.013 & -0.012 & $0.225^{*}$ & $0.132 *$ & 0.306 & 0.184 \\
\hline & $(0.191)$ & $(0.117)$ & $(0.124)$ & $(0.073)$ & $(0.282)$ & $(0.170)$ \\
\hline Corruption & $\begin{array}{c}0.184 * * \\
(0.084)\end{array}$ & $\begin{array}{c}0.112 * * \\
(0.051)\end{array}$ & $\begin{array}{c}0.283 * * * \\
(0.054)\end{array}$ & $\begin{array}{c}0.161 * * * \\
(0.031)\end{array}$ & $\begin{array}{c}0.066 \\
(0.129)\end{array}$ & $\begin{array}{c}0.043 \\
(0.077)\end{array}$ \\
\hline Sector & $\begin{array}{c}0.576^{* * *} \\
(0.098)\end{array}$ & $\begin{array}{c}0.352 * * * \\
(0.061)\end{array}$ & $\begin{array}{c}0.710^{* * * *} \\
(0.064)\end{array}$ & $\begin{array}{c}0.413 * * * \\
(0.037)\end{array}$ & $\begin{array}{c}0.595 * * * \\
(0.131)\end{array}$ & $\begin{array}{c}0.358^{* * * *} \\
(0.079)\end{array}$ \\
\hline $\mathrm{N}$ & 2,277 & 2,277 & 6,368 & 6,368 & 1,350 & 1,350 \\
\hline Pseudo R2 & 0.037 & 0.036 & 0.060 & 0.060 & 0.036 & 0.036 \\
\hline
\end{tabular}

***Significance at $1 \%$ level; **Significance at $5 \%$ level; *Significance at $10 \%$ level. Robust standard errors in parentheses.

\section{Source: Author calculations}

The results clearly imply that, regardless of the region, enterprise size and sector have significant positive impacts on product innovation. This result is consistent with our findings in the previous section for all BEEPS countries, and it further confirms that bigger enterprises innovate more due to larger R\&D budgets (Cohen \& Klepper, 1996) and greater availability of new technology. Moreover, sub-sample results convey that state ownership is insignificant for product innovation in all regions, which supports our findings for the whole sample and contradicts the conclusion of Ayyagari et al. (2007) that the innovative activity of SOE is lower.

\footnotetext{
${ }^{10}$ Share of state ownership is omitted because it predicts failure perfectly.
} 
Our results also show that the duration of enterprise existence is significant only for former Soviet countries, which means that enterprises with longer periods of existence innovate less. This trend can be due to the fact that in former Soviet countries enterprises that have existed for longer periods of time are relics of the previous economic system and are therefore heavily protected by the state with preferential market treatment that protects them from innovation pressures. One additional factor that leads to higher levels of innovation in former Soviet countries is the presence of soft budget constraints. Enterprises in this region are faced with difficult access to financing due to a large amount of non-performing loans (at the end of 2015 in Russia only, 7.4\% of total gross loans were nonperforming bank loans ${ }^{11}$ ), high interest rates, and banks not wanting to finance risky innovative projects. Therefore, enterprises use the presence of soft budget constraints and financing from state-owned banks or government agencies to increase their R\&D budgets and thus their ability to innovate.

The reasoning behind the positive effect of corruption on innovation levels in Balkan and former Soviet countries and the absence of this effect in Central European countries can be found in Lui (1985) and Murphy et al. (1993). Lui (1985) explains that corruptive activities will free resources that would otherwise be wasted on waiting for an ill-functioning bureaucracy, thus providing enterprises with a possibility to streamline these resources towards innovation. Building on this argument, Murphy et al. (1993) explain that enterprises wanting to innovate depend to a greater extent on government-supplied services and will therefore pay higher bribes prior to starting the process of innovation. Within Central European countries, most of the government services are automated and processed online, while Balkan and former Soviet countries are still considered to be heavily bureaucratised, thus enabling higher levels of public rent-seeking (bribes). For that reason, enterprises in Balkan and former Soviet countries usually opt for paying bribes in order to save time and resources that can be used for other activities such as innovation. Therefore, our results seem to provide support for the arguments of Murphy et al. (1993) since government and institutional efficiency ${ }^{12}$ in Balkan and former Soviet countries is lower than in Central European countries, leaving room for the positive pass-through effect of corruption on product innovation.

Results in Table 3 also imply that the possession of an international certificate and higher levels of top management experience lead to an increase in product innovation in Balkan and former Soviet countries, while these do not create any

\footnotetext{
${ }^{11}$ In 2015: Armenia - 9.1\%, Belarus - 5.1\%, Georgia - 3.3\%, Kazakhstan - 12.4\%, Moldova - 14.4\%, Ukraine - 24.3\%. In 2014: Azerbaijan - 12.7\%, Kyrgyzstan - 4.5\%, Tajikistan - 21.2\%, Uzbekistan $0.4 \%$. Source: The World Bank - World Development Indicators, last available data.

${ }^{12}$ According to the World Economic Forum's annual Global Competitiveness Report (2016), most Balkan and former Soviet countries have low rankings when it comes to the efficiency of government (efficiency measured including wastefulness of government spending, burden of regulation, and transparency of policy making).
} 
changes in innovation levels in Central European countries. Enterprises from Central European countries, unlike those from Balkan and former Soviet countries, operate within a framework of functional markets where strict government rules and customer expectations set relatively high standards even in the initial phases. Furthermore, innovation in these countries is promoted for a longer period of time, and the culture of innovation is present from primary school throughout. Therefore, the introduction of one additional international certificate within an enterprise in these countries creates a marginal effect on the already set and well-established innovative corporate culture, thus not impacting their innovation levels. Contrary to that, obtaining an international certificate and/or introducing an international standard within enterprises in Balkan and former Soviet countries enables them to channel resources more effectively and set out procedures that establish a focus for better resources management. For all these reasons, the possession of an international certificate in these countries provides ground for the creation of a corporate environment conducive to innovation, thus explaining its positive impact on the level of product innovation.

When it comes to top management experience, individuals in Central European countries are exposed to the culture of innovation from a young age, are provided with an opportunity to develop an innovator's mindset and learn how to transform their idea into reality. For these reasons, the experience of top management has a marginal effect on the innovation level within enterprises from these countries. On the other hand, in Balkan and former Soviet countries, innovation is underdeveloped and underestimated, which implies that the establishment of an innovative corporate culture is highly dependent on the tone from the top (top management behaviour). Therefore, top managers with greater levels of experience in these countries are able to recognise the importance of innovation, create an innovative atmosphere within the enterprise, and streamline R\&D funds towards projects that generate higher levels of innovation.

The results also show that the level of competition has a significant positive impact on product innovation in Central European and former Soviet countries, while it is insignificant for innovation levels within enterprises in Balkan countries. This finding could be due to the presence of higher competition pressures in the markets of Central European and former Soviet countries, which are also exposed to competition coming from global markets in a large number of cases. Contrary to that, competition in Balkan countries is still underdeveloped, and enterprises are not fully exposed to competition pressures from EU countries. Therefore, enterprises from Central European and former Soviet countries that are faced with intense competition, unlike enterprises from Balkan countries, innovate more in order to stay relevant market players and keep their market share. This conclusion confirms the finding of Allen and Gale (2000) that enterprises in developing countries that are exposed to high levels of competition have to be focussed on innovation and effective investments. Furthermore, our results are in line with the 
argument of Carlin et al. (2001) who explain that enterprises faced with fierce competition pressures are more likely to introduce a new product.

\section{Conclusion}

Rapid technological change and fierce competition on the world markets have created additional incentives for enterprise innovation. Innovation became especially important for enterprises originating from transition and developing countries as they at once needed to start competing with big global players. For that reason, innovation-based sustainability became one of the most important parameters for enterprise success. On the other hand, the crisis of 2008 forced many governments to reverse the process of privatisation, which increased the level of state ownership worldwide. Furthermore, fiscal constraints started limiting government ability to support loss-incurring SOEs. Bearing in mind these developments, our paper focussed on innovation-based sustainability of SOEs.

In our paper, we investigated which factors influence product innovation of enterprises, and we examined whether corruption and state ownership are important determinants of innovation-based sustainability. We have used enterprise-level data from the BEEPS 2012-2014 database and cross section analysis.

The findings revealed that big manufacturing enterprises with experienced top management have higher levels of product innovation. Moreover, contrary to previous literature that implied that state ownership has a negative influence on innovation levels, we have found no support for that standing. The results also indicated that corruption leads to an increase in product innovation. The reasoning behind this result is that enterprises faced with rent-seeking government officials opt for paying bribes in order to preserve their resources and time necessary for the innovation process. Furthermore, we conclude that enterprises faced with fierce competition pressures have higher levels of innovation. This is in line with the findings of previous research studies that enterprises with many competitors and desire to keep their market share are more likely to introduce new products.

Grouping the sample countries into three distinct regions enabled us to perceive similarities and differences among factors that influence product innovation in each of these regions. We found that bigger enterprises from the manufacturing sector have higher levels of product innovation regardless of the region. This is consistent with previous literature, as bigger enterprises are expected to have greater $R \& D$ budgets, while enterprises in manufacturing sectors have greater access to new technology, which is one of the key preconditions for an increase in innovation activity. Moreover, we found that corruption, top management expertise, and the possession of international quality assurance certificate increase innovation levels in Balkan and former Soviet countries, while they are insignificant for innovation levels in Central European countries. Enterprises in Balkan and former Soviet 
countries are exposed to inefficient and heavily bureaucratised public administration due to which they pay bribes in order to obtain permits and certificates that lead to innovation. Contrary to that, in Central European countries, most of these procedures are available online and are automatically processed, which marginalises the effect of corruption on innovation in this context. Our results also implied that higher levels of competition in Central European and former Soviet countries have a positive impact on product innovation, while this is insignificant for enterprises from Balkan countries. Such a finding is related to the greater exposure of enterprises from Central European and former Soviet countries to global competition, whereas enterprises from Balkan countries still do not feel a need to fight back competition through product innovation due to low competition pressures.

Our paper contributes to the existing literature through the provision of better understanding of the relationship between corruption, state ownership, market competition, top management experience, and product innovation. The analysis provided within this paper has a significant implication for anti-corruption policy as well as for the creation of country-based innovation culture. Within our future research, we will attempt to investigate the effects of other forms of corruption on innovation activity, as well as depict whether financing options that are available for enterprises influence innovation levels within countries.

\section{References}

Aghion, P., Blundell, R., Griffith, R., Howitt, P., \& Prantl, S. (2009). The effects of entry on incumbent innovation and productivity. The Review of Economics and Statistics, 91(1), 20-32.

Aghion, P., Carlin, W., \& Schaffer, M. (2002). Competition, innovation and growth in transition: Exploring the interactions between policies. William Davidson Working Paper 501. The William Davidson Institute.

Aghion, P., \& Howitt, P. (1992). A model of growth through creative destruction. Econometrica, 60, 323-351.

Ahn, S. (2002). Competition, innovation and productivity growth: A review of theory and evidence. OECD. Economics Department Working Papers 317, 1-78.

Allen, F., \& Gale, D. (2000). Comparing financial systems. Cambridge, Massachusetts: MIT Press.

Anokhin, S., \& Schulze, W. S. (2009). Entrepreneurship, innovation and corruption. Journal of Business Venturing, 24(5), 465-476.

Asiedu, E., \& Freeman, J. A. (2009). The effect of corruption on investment growth: Evidence from firms in Latin America, Sub-Saharan Africa and transition countries. Review of Development Economics, 13(2), 200-214.

Aubert, J.-E. (2005). Promoting innovation in developing countries. World Bank Policy Research Working Papers, No. 3554. 
Ayyagari, M., Demirgtic-Kunt, A., \& Maksimovic, V. (2011). Firm innovation in emerging markets: The role of finance, governance and competition. Journal of Financial and Quantitative Analysis, 46(6), 1545-1580.

Ayyagari, M., Demirgtic-Kunt, A., \& Maksimovic, V. (2010). Are innovating firms victims or perpetrators? Tax evasion, bribe payments, and the role of external finance in developing countries. Policy Research Working Paper Series 5389, The World Bank.

Ayyagari, M., Demirgtic-Kunt, A., \& Maksimovic, V. (2007). Firm innovation in emerging markets: The roles of governance and finance. Policy Research Working Paper Series 4157, The World Bank.

Baumol, W. J. (1980). Public and private enterprises in a mixed economy (ed.). New York: St. Martin's Press.

Bellos, S., \& Subasat, T. (2012). Corruption and foreign direct investment: A panel gravity model approach. Bulletin of Economic Research, 64(4), 565-574.

Bloom, N., \& Reenen, J. V. (2010). Why do management practices differ across firms and countries? The Journal of Economic Perspective, 24(1), 203-224.

Blundell, R., Griffith, R., \& Van Reenen, J. (1999). Market share, market value and innovation in a panel of British manufacturing firms. Review of Economic Studies, 66, 529-554.

Boardman, A. F., \& Vining, A. R. (1989). Ownership and performance in competitive environments: A comparison of the performance of private, mixed, and state-owned enterprises. Journal of Law and Economics, 32, 1-33.

Bozec, R., Breton, G., \& Cote, L. (2002). The performance of state-owned enterprises revisited. Financial Accountability and Management, 18(4), 383-407.

Brown, A. (1995). Should Telstra be privatized? Paper presented at the $24^{\text {th }}$ Conference of Economics, Griffith University, Adelaide.

Cameron, G. (1996). Innovation and economic growth. CEPDP, 277. Centre for Economic Performance, London School of Economics and Political Science, London, UK.

Campos, N. F., Dimova, R., \& Saleh, A. (2010). Whither corruption? A quantitative survey of the literature on corruption and growth. IZA Discussion Paper. Institute for the study of Labor (IZA).

Capobianco, A., \& Christiansen, H. (2011). Competitive neutrality and state-owned enterprises: Challenges and policy options. OECD Corporate Governance Working Papers No. 1, OECD Publishing, Paris, France.

Carlin, W., Fries, S., Schaffer, M., \& Seabright, P. (2001). Competition and enterprise performance in transition economies: Evidence from a cross-country survey. Working Paper 63. EBRD, London, UK.

Chang, J. (2007). State-owned enterprise reform. United Nations Department for Economic and Social Affairs (UNDESA), New York, USA.

Christiansen, H. (2013). Balancing commercial and non-commercial priorities of state-owned enterprises. OECD Corporate Governance Working Papers No. 6, OECD Publishing, Paris, France.

Cohen, W. M., \& Klepper, S. (1996). Firm size and the nature of innovation within industries: The case of process and product R\&D. The Review of Economic and Statistics, 78(2), 232-243.

Cox, R. F., Issa, R. R. A., \& Ahrens, D. (2003). Management's perception of key performance indicators for construction. Journal of Construction, Engineering and Management, 129(2), 142-151. 
De Rosa, D., Gooroochurn, N., \& Gorg, H. (2010). Corruption and productivity firm-level evidence from BEEPS survey. Kiel Working Paper 1632. Kiel Institute for the World Economy, Kiel, Germany.

Freeman, C., \& Soete, L. (1997). The economics of industrial innovation ( $3^{\text {rd }}$ edition). London: Pinter.

Fries, S., Lysenko, T., \& Polenac, S. (2003). The 2002 business environment and enterprise performance survey: Results from a survey of 6,100 firms. EBRD Working paper 84, EBRD, London, UK.

Furman, J. L., Porter, M. E., \& Stern, S. (2002). The determinants of national innovative capacity. Research Policy, 32(6), 899-933.

Gaviria, A. (2002). Assessing the effects of corruption and crime on firm performance: Evidence from Latin America. Emerging Markets Review, 3, 245-268.

Grossman, G. M., \& Helpman, E. (1991). Innovation and Growth in the Global Economy. MIT Press.

Habiyaremye, A., \& Raymond, W. (2013). Transnational corruption and innovation in transition economies. UNU-MERIT Working Papers. Maastricht Economic and Social Research Institute on Innovation and Technology.

Hana, U. (2013). Competitive advantage achievement through innovation and knowledge. Journal of Competitiveness, 5(1), 82-96.

Hansen, J. A. (1992). Innovation, firm size and firm age. Small Business Economics, 4(1), $37-$ 44.

Hellman, J. S., Jones, G., \& Kaufmann, D. (2003). Seize the state, seize the day: State capture and influence in transition economies. Journal of Competitive Economics, 31, 751-773.

Hellman, J. S., Jones, G., \& Kaufmann, D. (2000). Seize the state, seize the day: State capture, corruption and influence in transition. World Bank Working Paper 2444. World Bank, Washington, USA.

Holcomb, T. R., Holmes, M. R. Jr., \& Connely, B. L. (2009). Making the most of what you have: Managerial ability as a source of resource value creation. Strategic Management Journal, 30(5), 457-485.

Huntington, S. P. (1968). Political order in changing societies. New Haven: Yale University Press.

Jensen, M. C., \& Meckling, W. H. (1976). Theory of the firm: Managerial, behavior, agency costs and ownership structure. Journal of Financial Economics, 3, 305-360.

Kaufmann, D., \& Wei, S.-J. (2000). Does grease money speed up the wheels of commerce? IMF Working Paper 00/64. IMF, Washington, USA.

Krammer, S. M. S. (2013, June). Greasing the wheels of change: The impact of corruption on firms? Innovation in transition economies. Paper presented at $35^{\text {th }}$ Druid Celebration Conference, Barcelona, Spain.

Kueng, P. (2000). Process performance measurement system: A tool to support process-based organizations. Total Quality Management, 11(1), 67-85.

La Porta, R., Lopez-de-Silanes, F., Shleifer, A., \& Vishny, R. (2002). Investor protection and corporate valuation. The Journal of Finance, 57(3), 1147-1170.

Laux, J. K., \& Molot, M. A. (1988). State capitalism: Public enterprise in Canada. Cornell University.

Lederman, D. (2010). An international multilevel analysis of product innovation. Journal of International Business Studies, 41(4), 606-619.

Leff, N. H. (1964). Economic development through bureaucratic corruption. American Behavioral Scientist, 8, 8-14. Reprint in A. J. Heidenhaimer, M. Johnson, \& V. T. Le 
Vine (Eds.), Political corruption: A handbook (pp. 389-403). Oxford: Transaction Books.

Leys, C. (1965). What is the problem about corruption? Journal of Modern African Studies, 3, 215-230. Reprint in A. J. Heidenhaimer, M. Johnson, \& V. T. Le Vine (Eds.), Political corruption: A handbook (pp. 389-403). Oxford: Transaction Books.

Lui, F. T. (1985). An equilibrium queuing model of bribery. Journal of Political Economy, 93, 760-781.

Luo, Y. (2005). An organizational perspective of corruption. Management and Organizational Review, 1(1), 119-154.

Mahagaonkar, P. (2009). Corruption and innovation. International Studies in Entrepreneurship, 25, 81-97.

McCann, P., \& Oxley, L. (2012). Innovation, entrepreneurship, geography and growth. Journal of Economic Surveys, 26(3), 373-376.

Megginson, W. L., Nash, N. C., \& Van Randenborgh, M. (1994). The financial and operating performance of newly privatized firms: An international empirical analysis. Journal of Finance, 49, 403-452.

Mitra, P., Muravyev, A., \& Schaffer, M. E. (2009). Convergence in institutions and market outcomes. Policy Research Working Paper 4819. World Bank, Washington, USA.

Molero, J., \& Garcia, A. (2008). Factors affecting innovation revisited. WP 05/08. Instituto Complutense de Estudios Internacionales, Universidad Complutense de Madrid. Campus de Somosaguas.

Musacchio, A., Pineda Ayerbe, E. I., \& García, G. (2015). State-owned enterprise reform in Latin America: Issues and possible solutions. Inter American Development Bank discussion paper No. IDB-DP-401.

Musacchio, A. (2013). The Ivey Business Journal interview: Aldo Musacchio. Ivey Business Journal.

Murphy, K. M., Shleifer, A., \& Vishny, R.W. (1993). Why is rent-seeking so costly to growth? American Economic Review, 83(2), 409-414.

Nickell, S. (1996). Competition and corporate performance. Journal of Political Economy, 104, 724-746.

OECD. (2015). Guidelines on corporate governance of state-owned enterprises. OECD Publishing, Paris, France.

OECD. (2011). State-owned enterprises governance reform: An inventory of recent change. OECD Publishing, Paris, France.

OECD. (2005). Oslo manual: Guidelines for collecting and interpreting innovation data. $3^{\text {rd }}$ Edition, OECD Publishing, Paris, France.

OECD. (1999). From boosting innovation: The cluster approach. OECD Proceedings. OECD, Paris, France.

Raffo, J., Ghuillery, S., \& Miotti, L. (2008). Northern and southern innovativity: A comparison across European and Latin American countries. European Journal of Development Research, 20(2), 219-239.

Romer, P. M. (1990). Endogenous technological change. Journal of Political Economy, 98(5), S71-S102.

Rosenberg, N. (2004). Innovation and economic growth. OECD, Paris, France.

Rothwell, R. (1994). Towards the fifth-generation innovation process. International Marketing Review, 11(1), 7-31.

Sawang S. (2011). Key performance indicators for innovation implementation: Perceptions vs. actual usage. Asia Pacific Management Review. 16(1), 23-29. 
Schumpeter, J. A. (1911). Theorie der wirtschaftlichen entwicklung. American Journal of Economics and Sociology, 61(2), 405-437.

Shleifer, A. (1998). State versus private ownership. Journal of Economic Perspective, 12, 133-150.

Shleifer, A., \& Vishny, R. W. (1993). Corruption. The Quarterly Journal of Economics. 108(3), 599-617.

Vial, V., \& Hanoteau, J. (2010). Corruption, manufacturing plant growth, and the Asian paradox: Indonesian evidence. World Development, 38(5), 693-705.

Waldemar, F. S. (2012). New products and corruption: Evidence from Indian firms. The Developing Economies, 50(3), 268-284.

Wang, L., \& Yung, K. (2011). Do state enterprises manage earnings more than privately owned firms? The case of China. Journal of Business Finance and Accounting, 38(7), 794-812.

Wong, S. C. Y. (2004). Improving corporate governance in SOEs: An integrated approach. Corporate Governance International, 7(2), 5-15.

World Bank. (2014). Corporate governance of state-owned enterprises: A toolkit. DOI: 10.1596/978-1-4648-0222-5, World Bank, Washington DC, USA.

World Bank. (2006). Held by the visible hand: The challenge of SOE corporate governance for emerging markets. World Bank, Washington, USA.

World Bank. (1995). Bureaucrats in business - the economics and politics of government ownership. New York: Oxford University Press.

World Economic Forum. (2016). Global competitiveness report 2015-2016. World Economic Forum, Geneva.

\section{FAKTORI ODRŽIVOSTI KOJA JE ZASNOVANA NA INOVACIJAMA U ZEMLJAMA U TRANZICIJI I RAZVOJU}

Apstrakt: Tehnološki napredak koji je nastao kao posledica većeg stepena konkurencije u globalizovanom svetu doveo je do ubrzanja inovativnih aktivnosti. Literatura pokazuje da korupcija, udeo države u vlasništvu, i stručnost najvišeg rukovodstva mogu imati snažan uticaj na učinak kompanija i njihovu održivost koja je zasnovana na inovacijama. Koristeći BEEPS 20122014 bazu podataka, ovaj rad primjenjuje cross-section analizu kako bi ispitao koji faktori utiču na inovacije kompanija. Naši rezultati pokazuju da veće proizvodne kompanije sa iskusnim višim rukovodstvom i međunarodnim sertifikatima za garanciju kvaliteta koja posluju u okruženjima sa povećanim stepenom korupcije i konkurencije imaju viši nivo inovacija. Pored toga, rezultati pokazuju da je državno vlasništvo zanemarljivo za inovativne aktivnosti. Što se tiče regionalne analize, rezultati ukazuju na to da korupcija, iskustvo najvišeg rukovodstva, i posedovanje međunarodnih sertifikata za garanciju kvaliteta dovode do povećanog stepena inovacija proizvoda na Balkanu i u zemljama bivšeg Sovjetskog Saveza, dok ovi faktori nemaju značajan uticaj na inovativne aktivnosti unutar zemalja Centralne Evrope. Kompanije suočene sa visokim stepenom konkurencije su inovativnije $u$ bivšim sovjetskim i centralnoevropskim zemljama nego na Balkanu.

Ključne reči: inovacija, konkurencija, korupcija, državne kompanije 


\section{Authors' biographies}

Tanja Kuzman holds a PhD in Finance of the University of Sheffield, UK. Her broad research interests are related to corporate finance, corporate governance, behaviour of state-owned enterprises, political embeddedness, big-data analytics, start-up financing, and transition economies. She was a Marie Curie Fellow on EU-funded GREY project and a consultant on several corporate governance projects of the International Finance Corporation, the World Bank Group.

Sotirios K. Bellos is a Lecturer at the International Faculty-CITY College, University of Sheffield, where he teaches Monetary Economics, Banking and International Finance. His research interests lie in the field of finance and its association with macroeconomics, as well as FDI and geo-economics. His research work has appeared in the Bulletin of Economic Research, International Review of Applied Economics and Foreign Affairs. He also holds a position of Sector Head in the Corporate Restructuring Division of National Bank of Greece.

Katarina Đulić is an Associate Professor at Faculty of Economics, Finance and Administration in Belgrade, Serbia where she teaches undergraduate and graduate courses in Corporate Finance and Corporate Governance. She holds a Bachelor of Laws from the University of Belgrade, a Master of Laws (LL.M.) from Northwestern University, a Master in Public Policy from Harvard University, and a PhD in Economics from the University of Belgrade. Ms. Đulić worked as a project manager for the Serbian and Montenegrin Corporate Governance Projects of the International Finance Corporation, World Bank, at the Ministry of Finance, of the Republic of Serbia, first as an adviser to the Minister and then as an Assistant Minister in charge of the Financial System Division. She also worked for the European Bank for Reconstruction and Development in London and as Senior consultant at KPMG. Her research interests include corporate and public finance, corporate and public sector governance, women in economic decision-making, local economic development and financing of small and medium enterprises. 


\section{APPENDIX A}

Table 1. Variables and corresponding questions from BEEPS

\begin{tabular}{|c|c|}
\hline Variable & BEEPS 2012-2014 \\
\hline Product innovation & $\begin{array}{l}\text { H1 } \\
\text { During the last three years, has this establishment } \\
\text { introduced new or significantly improved products or } \\
\text { services? Please exclude the simple resale of new goods } \\
\text { purchased from others and changes of a solely aesthetic } \\
\text { nature. }\end{array}$ \\
\hline Share of state ownership & $\begin{array}{l}\mathrm{B} 2 \mathrm{c} \\
\text { What percentage of this firm is owned by Government or } \\
\text { State? }\end{array}$ \\
\hline Enterprise size & $\begin{array}{l}\text { L1 } \\
\text { At the end of the fiscal year, how many permanent, full } \\
\text { time individuals worked in this establishment? Please } \\
\text { include all employees and managers. }\end{array}$ \\
\hline Enterprise existence & $\begin{array}{l}\text { B5 } \\
\text { In what year did this establishment begin operations? }\end{array}$ \\
\hline Top management experience & $\begin{array}{l}\text { B7 } \\
\text { How many years of experience working in this sector does } \\
\text { the Top Manager have? }\end{array}$ \\
\hline Certificate & $\begin{array}{l}\text { B8 } \\
\text { Does this establishment have an internationally-recognised } \\
\text { quality certification? }\end{array}$ \\
\hline Competition & $\begin{array}{l}\text { E2b } \\
\text { In a fiscal year, for the main market in which this } \\
\text { establishment sold its main product, how many competitors } \\
\text { did this establishment's main product face? }\end{array}$ \\
\hline Soft budget constraint & $\begin{array}{l}\text { K9 } \\
\text { Referring to the most recent line of credit or loan, what type } \\
\text { of financial institution granted this loan? }\end{array}$ \\
\hline Corruption & $\begin{array}{l}\text { ECAq39 } \\
\text { It is common for firms in my line of business to have to pay } \\
\text { some irregular "additional payments or gifts" to get things } \\
\text { done with regard to customs, taxes, licenses, regulations, } \\
\text { services, etc. }\end{array}$ \\
\hline Sector & $\begin{array}{l}\mathrm{A} 4 \mathrm{~b} \\
\text { Industry - Screener sector }\end{array}$ \\
\hline
\end{tabular}

Source: Authors' calculations 


\section{APPENDIX B}

Table 1. Balkan countries

\begin{tabular}{|c|c|c|c|c|c|c|}
\hline & OLS & $\begin{array}{c}\text { OLS } \\
\text { (country } \\
\text { dummy) }\end{array}$ & LOGIT & $\begin{array}{l}\text { LOGIT } \\
\text { (country } \\
\text { dummy) }\end{array}$ & PROBIT & $\begin{array}{l}\text { PROBIT } \\
\text { (country } \\
\text { dummy) }\end{array}$ \\
\hline \multirow{2}{*}{$\begin{array}{l}\text { Share of state } \\
\text { ownership }\end{array}$} & -0.306 & -0.311 & -1.578 & -1.586 & -0.902 & -0.932 \\
\hline & $(0.227)$ & $(0.217)$ & $(1.379)$ & $(1.348)$ & $(0.807)$ & $(0.779)$ \\
\hline \multirow[t]{2}{*}{ Enterprise size } & $0.018 * *$ & 0.010 & $0.081 * *$ & 0.048 & $0.050 * *$ & 0.030 \\
\hline & $(0.009)$ & $(0.009)$ & $(0.041)$ & $(0.042)$ & $(0.025)$ & $(0.026)$ \\
\hline \multirow{2}{*}{$\begin{array}{l}\text { Enterprise } \\
\text { existence }\end{array}$} & 0.012 & 0.018 & 0.059 & 0.089 & 0.035 & 0.048 \\
\hline & $(0.017)$ & $(0.017)$ & $(0.079)$ & $(0.081)$ & $(0.047)$ & $(0.049)$ \\
\hline \multirow{2}{*}{$\begin{array}{l}\text { Top management } \\
\text { experience }\end{array}$} & $0.030^{*}$ & 0.003 & $0.142 *$ & 0.019 & $0.086^{*}$ & 0.015 \\
\hline & $(0.016)$ & $(0.016)$ & $(0.076)$ & $(0.079)$ & $(0.046)$ & $(0.048)$ \\
\hline Certificate & $\begin{array}{c}0.128 * * * \\
(0.024)\end{array}$ & $\begin{array}{c}0.123 * * * \\
(0.024)\end{array}$ & $\begin{array}{c}0.562 * * * \\
(0.103)\end{array}$ & $\begin{array}{c}0.561^{* * * *} \\
(0.107)\end{array}$ & $\begin{array}{c}0.345^{* * *} \\
(0.063)\end{array}$ & $\begin{array}{c}0.343 * * * \\
(0.065)\end{array}$ \\
\hline Competition & $\begin{array}{l}-0.008 \\
(0.011)\end{array}$ & $\begin{array}{l}-0.012 \\
(0.011)\end{array}$ & $\begin{array}{l}-0.036 \\
(0.051)\end{array}$ & $\begin{array}{l}-0.062 \\
(0.052)\end{array}$ & $\begin{array}{l}-0.022 \\
(0.031)\end{array}$ & $\begin{array}{l}-0.039 \\
(0.032)\end{array}$ \\
\hline \multirow{2}{*}{$\begin{array}{l}\text { Soft } \\
\text { constraint }\end{array}$} & -0.002 & -0.007 & -0.013 & -0.037 & -0.012 & -0.030 \\
\hline & $(0.041)$ & $(0.044)$ & $(0.191)$ & $(0.209)$ & $(0.117)$ & $(0.129)$ \\
\hline Corruption & $\begin{array}{c}0.040 * * \\
(0.018)\end{array}$ & $\begin{array}{c}0.052 * * * \\
(0.018)\end{array}$ & $\begin{array}{c}0.184 * * \\
(0.084)\end{array}$ & $\begin{array}{c}0.255^{* * *} * \\
(0.089)\end{array}$ & $\begin{array}{c}0.112 * * \\
(0.051)\end{array}$ & $\begin{array}{c}0.156^{* * * *} \\
(0.054)\end{array}$ \\
\hline Sector & $\begin{array}{c}0.130 * * * \\
(0.023)\end{array}$ & $\begin{array}{c}0.133 * * * \\
(0.022)\end{array}$ & $\begin{array}{c}0.576 * * * \\
(0.098)\end{array}$ & $\begin{array}{c}0.618 * * * \\
(0.102)\end{array}$ & $\begin{array}{c}0.352 * * * \\
(0.061)\end{array}$ & $\begin{array}{c}0.374 * * * \\
(0.062)\end{array}$ \\
\hline $\mathrm{N}$ & 2,277 & 2,277 & 2,277 & 2,277 & 2,277 & 2,277 \\
\hline $\mathrm{R} 2$ & 0.047 & 0.090 & & & & \\
\hline Pseudo R2 & & & 0.037 & 0.075 & 0.036 & 0.075 \\
\hline
\end{tabular}

Source: Authors' calculations 
Kuzman et al. / Economic Themes, 56(3): 413-438 437

Table 2. Former Soviet countries

\begin{tabular}{|c|c|c|c|c|c|c|}
\hline & OLS & $\begin{array}{c}\text { OLS } \\
\text { (country } \\
\text { dummy) } \\
\end{array}$ & LOGIT & $\begin{array}{l}\text { LOGIT } \\
\text { (country } \\
\text { dummy) } \\
\end{array}$ & PROBIT & $\begin{array}{l}\text { PROBIT } \\
\text { (country } \\
\text { dummy) }\end{array}$ \\
\hline Share of state ownership & $\begin{array}{l}-0.037 \\
(0.061)\end{array}$ & $\begin{array}{l}-0.043 \\
(0.061)\end{array}$ & $\begin{array}{l}-0.218 \\
(0.364)\end{array}$ & $\begin{array}{l}-0.195 \\
(0.371)\end{array}$ & $\begin{array}{l}-0.134 \\
(0.212)\end{array}$ & $\begin{array}{l}-0.134 \\
(0.219)\end{array}$ \\
\hline Enterprise size & $\begin{array}{c}0.045 * * * \\
(0.005)\end{array}$ & $\begin{array}{c}0.041 * * * \\
(0.005)\end{array}$ & $\begin{array}{c}0.250 * * * \\
(0.027)\end{array}$ & $\begin{array}{c}0.238 * * * \\
(0.029)\end{array}$ & $\begin{array}{c}0.146^{* * * *} \\
(0.016)\end{array}$ & $\begin{array}{c}0.139 * * * \\
(0.017)\end{array}$ \\
\hline Enterprise existence & $\begin{array}{l}-0.015^{*} \\
(0.008)\end{array}$ & $\begin{array}{l}-0.005 \\
(0.008)\end{array}$ & $\begin{array}{l}-0.093^{*} \\
(0.048)\end{array}$ & $\begin{array}{c}-0.041 \\
(0.050)\end{array}$ & $\begin{array}{l}-0.052^{*} \\
(0.028)\end{array}$ & $\begin{array}{l}-0.022 \\
(0.029)\end{array}$ \\
\hline $\begin{array}{l}\text { Top management } \\
\text { experience }\end{array}$ & $\begin{array}{c}0.031 * * * \\
(0.008)\end{array}$ & $\begin{array}{c}0.027 * * * \\
(0.007)\end{array}$ & $0.196 * * *$ & $0.176^{* * *}$ & $0.110 * * *$ & $\begin{array}{c}0.096 * * * \\
(0.028)\end{array}$ \\
\hline Certificate & $\begin{array}{c}0.077 * * * \\
(0.017)\end{array}$ & $\begin{array}{c}0.075 * * * \\
(0.017)\end{array}$ & $\begin{array}{c}0.384 * * * \\
(0.087)\end{array}$ & $\begin{array}{c}0.397 * * * \\
(0.089)\end{array}$ & $\begin{array}{c}0.232 * * * \\
(0.052)\end{array}$ & $\begin{array}{c}0.232 * * * \\
(0.053)\end{array}$ \\
\hline Competition & $\begin{array}{c}0.033 * * * \\
(0.007)\end{array}$ & $\begin{array}{c}0.021 * * * \\
(0.007)\end{array}$ & $\begin{array}{c}0.191 * * * \\
(0.041)\end{array}$ & $\begin{array}{c}0.126^{* * * *} \\
(0.042)\end{array}$ & $\begin{array}{c}0.109 * * * \\
(0.024)\end{array}$ & $\begin{array}{c}0.075 * * * \\
(0.024)\end{array}$ \\
\hline Soft budget constraint & $\begin{array}{l}0.044^{*} \\
(0.023)\end{array}$ & $\begin{array}{c}0.021 \\
(0.023)\end{array}$ & $\begin{array}{l}0.225^{*} \\
(0.124)\end{array}$ & $\begin{array}{c}0.103 \\
(0.127)\end{array}$ & $\begin{array}{l}0.132^{*} \\
(0.073)\end{array}$ & $\begin{array}{c}0.060 \\
(0.075)\end{array}$ \\
\hline Corruption & $\begin{array}{c}0.046^{* * * *} \\
(0.009)\end{array}$ & $\begin{array}{c}0.042 * * * \\
(0.009)\end{array}$ & $\begin{array}{c}0.283 * * * \\
(0.054)\end{array}$ & $\begin{array}{c}0.256^{* * *} \\
(0.056)\end{array}$ & $\begin{array}{c}0.161 * * * \\
(0.031)\end{array}$ & $\begin{array}{c}0.143 * * * \\
(0.032)\end{array}$ \\
\hline Sector & $\begin{array}{c}0.125 * * * \\
(0.012)\end{array}$ & $\begin{array}{c}0.144 * * * \\
(0.012)\end{array}$ & $\begin{array}{c}0.710 * * * \\
(0.064)\end{array}$ & $\begin{array}{c}0.850 * * * \\
(0.067)\end{array}$ & $\begin{array}{c}0.413 * * * \\
(0.037)\end{array}$ & $\begin{array}{c}0.497 * * * \\
(0.039)\end{array}$ \\
\hline $\begin{array}{l}\mathrm{N} \\
\mathrm{R} 2\end{array}$ & $\begin{array}{l}6,368 \\
0066\end{array}$ & $\begin{array}{l}6,368 \\
0,103\end{array}$ & 6,368 & 6,368 & 6,368 & 6,368 \\
\hline Pseudo R2 & & & 0.060 & 0.104 & 0.060 & 0.104 \\
\hline
\end{tabular}

Source: Authors' calculations. 
Table 3. Central European countries

\begin{tabular}{|c|c|c|c|c|c|c|}
\hline & OLS & $\begin{array}{c}\text { OLS } \\
\text { (country } \\
\text { dummy) } \\
\end{array}$ & LOGIT & $\begin{array}{l}\text { LOGIT } \\
\text { (country } \\
\text { dummy) } \\
\end{array}$ & PROBIT & $\begin{array}{l}\text { PROBIT } \\
\text { (country } \\
\text { dummy) }\end{array}$ \\
\hline \multirow{2}{*}{$\begin{array}{l}\text { Share of state } \\
\text { ownership }\end{array}$} & - & - & 0.000 & 0.000 & 0.000 & 0.000 \\
\hline & $\begin{array}{c}0.462 * * * \\
(0.055)\end{array}$ & $\begin{array}{c}0.396 * * * \\
(0.070)\end{array}$ & (.) & (.) & (.) & (.) \\
\hline Enterprise size & $\begin{array}{c}0.039 * * * \\
(0.011)\end{array}$ & $\begin{array}{c}0.035 * * * \\
(0.011)\end{array}$ & $\begin{array}{c}0.198 * * * \\
(0.054)\end{array}$ & $\begin{array}{c}0.188 * * * \\
(0.058)\end{array}$ & $\begin{array}{c}0.121 * * * \\
(0.033)\end{array}$ & $\begin{array}{c}0.113 * * * \\
(0.034)\end{array}$ \\
\hline \multirow{2}{*}{$\begin{array}{l}\text { Enterprise } \\
\text { existence }\end{array}$} & 0.020 & 0.001 & 0.106 & 0.005 & 0.061 & 0.001 \\
\hline & $(0.022)$ & $(0.022)$ & $(0.119)$ & $(0.128)$ & $(0.071)$ & $(0.075)$ \\
\hline \multirow{2}{*}{$\begin{array}{l}\text { Top management } \\
\text { experience }\end{array}$} & -0.007 & -0.009 & -0.038 & -0.052 & -0.021 & -0.028 \\
\hline & $(0.019)$ & $(0.019)$ & $(0.100)$ & $(0.105)$ & $(0.060)$ & $(0.062)$ \\
\hline \multirow[t]{2}{*}{ Certificate } & 0.013 & 0.029 & 0.074 & 0.145 & 0.042 & 0.077 \\
\hline & $(0.028)$ & $(0.028)$ & $(0.141)$ & $(0.154)$ & $(0.084)$ & $(0.090)$ \\
\hline \multirow[t]{2}{*}{ Competition } & $0.037 * *$ & $0.028 *$ & $0.188 * *$ & $0.152 *$ & $0.116^{* * *}$ & $0.096 * *$ \\
\hline & $(0.015)$ & $(0.015)$ & $(0.074)$ & $(0.077)$ & $(0.045)$ & $(0.046)$ \\
\hline \multirow{2}{*}{$\begin{array}{l}\text { Soft } \\
\text { constraint }\end{array}$} & 0.061 & 0.081 & 0.306 & 0.436 & 0.184 & 0.252 \\
\hline & $(0.060)$ & $(0.060)$ & $(0.282)$ & $(0.302)$ & $(0.170)$ & $(0.176)$ \\
\hline \multirow[t]{2}{*}{ Corruption } & 0.013 & -0.034 & 0.066 & -0.195 & 0.043 & -0.110 \\
\hline & $(0.025)$ & $(0.026)$ & $(0.129)$ & $(0.142)$ & $(0.077)$ & $(0.083)$ \\
\hline \multirow[t]{2}{*}{ Sector } & $0.119 * * *$ & $0.096 * * *$ & $0.595 * * *$ & $0.513 * * *$ & $0.358 * * *$ & $0.308 * * *$ \\
\hline & $(0.027)$ & $(0.027)$ & $(0.131)$ & $(0.137)$ & $(0.079)$ & $(0.081)$ \\
\hline $\mathrm{N}$ & 1,359 & 1,359 & 1,350 & 1,350 & 1,350 & 1,350 \\
\hline $\mathrm{R} 2$ & 0.043 & 0.096 & & & & \\
\hline Pseudo_R2 & & & 0.036 & 0.080 & 0.036 & 0.080 \\
\hline
\end{tabular}

Source: Authors' calculations 